\title{
INDIVIDUALIZED EDUCATION PLANS: WHAT CHARACTERIZES THE RESEARCH?
}

\author{
Carl Chr. Bachke \\ University of Agder, Norway
}

\begin{abstract}
This study illuminates the research question what characterizes the research of Special Needs Education's (SNE's) use of Individualized Education Plans (IEP), during the period 2010-2015? A sample of 11 relevant Norwegian publications has been analyzed by means of these criteria: Type of publication, research method(s) applied, sub-topics focused on and perspectives of SNE. Findings show (1) the amount of the research is still scarce, (2) only three researchers of PhD-level or above have participated in this sample of publications, (3) the sample demonstrates various research methods applied, although document analysis dominates, (4) there is still a need of research looking for catalysts of good planning and using of IEP, (5)the study presents one way of constructing thematic and sub-topical categories, and (6) one needs to validate how the SNE's perspectives of traditionalism and inclusionism influence the outcomes of IEP research.
\end{abstract}

Keywords: Individualized Education Plan, literature review, research methods, special needs education, inclusionism, traditionalism

\section{Introduction}

The aim of this study is to throw light on research linked to the use of Individualized Education Plans (IEP) within the field of Special Needs Education (SNE). In particular it is essential to highlight this field's research characteristics in Norway. Until relatively lately the school systems in the world based their teaching of pupils on general curriculum programs only - often of a kind of national standard. In the US the IEP was introduced during the 1970s (Aarnes, 2008). In Norway the first signs of the IEP were seen around 1990. The term Individualized Learning Plan (ILP) was introduced in governmental propositions (St.meld. no.54 (1989-90); St.meld. no.35 (1990-91). The latter explicitly stated the purpose of IEP by emphasizing that it should strengthen the education of children and youth with special needs. And the Education Act (§55) underpinned that an IEP should be worked out for all pupils who receive SNE. Nordahl \&Overland (1997:75) presented this definition of IEP:

"An individual education plan should state important issues and principles, related to the individual pupil's needs and readiness of learning and should, based upon the national curriculum's goals and decisions, contain concrete instructions that comprise the total educational situation of the pupil in such a way that the plan is transparent for critical investigation of others, and at the same time possible to implement in practice."

Their definition emphasizes three important aspects that are basic for the teacher to consider when he produces, uses and evaluates an IEP: (1) to have a 
thorough knowledge of the needs and readiness of each individual pupil; (2) to adapt the IEP to the goals and decisive values of the school's national curriculum; and (3) to make the IEP useful in practice. Figure 1 illustrates the relation between ordinary education, SNE and IEP. In many cases pupils that have an IEP are taught by a specialist teacher in separate rooms (often a segregated group). If it is only one pupil, he is taught individually in a corner of the common classroom, at least for some periods daily. In some cases a school might practice inverted inclusion where the non-IEP-pupils are included in the group of IEP pupils for some periods.

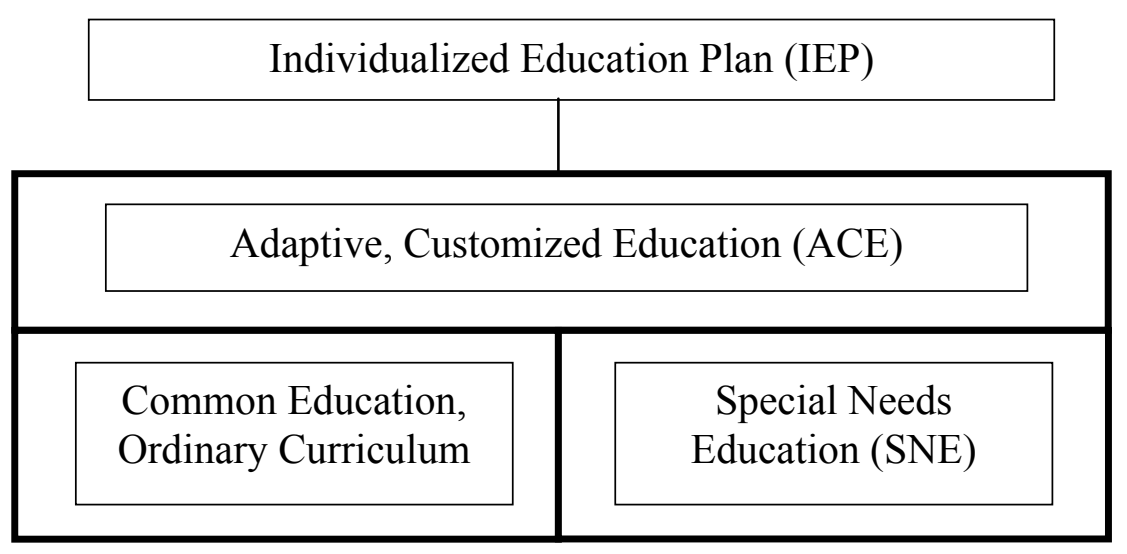

Figure 1. The links between common education, SNE, ACE and IEP (Based on Nordahl \& Overland, 1997:31)

Since the early 1990s different terms have been introduced to describe the IEP-phenomenon. In Norway these designations have been applied (translated to English, abbreviations in brackets): Individualized Learning Plan (ILP); Individualized Training Plan (ITP); Individualized Development Plan/ Development Plan (IDP/DP); Individualized Customized Teaching Plan (ICTP); and Individualized Education Plan (IEP). Different connotations are linked to the various terms.

The number of pupils receiving SNE in Norwegian primary school has increased since the last curriculum reform (Kunnskapsløftet, 2006). In 2006 the figure was approx. $6 \%$. It stabilized itself at $8.6 \%$ around 2011 . The highest registered rate, $11 \%$, is found in secondary schools (St.meld. no.20, 20122013). These figures indicate that the need for formulating and using IEPs in the Norwegian school system is significant. In 2011 Bachke contended that IEPs were much used. One may ask however, is this practice based on thorough empirical research? In 2011 Bachke claimed that the quantity of the research was scanty. Has there been any change during the last 5 years? If still scarce, many questions might be asked: What are the research's qualitative characteristics; what about its sub-topics; which research methods and perspectives have been applied? Thus the research question is: What characterizes the research of SNE's use of IEP, during the period 2010-2015? 
Before answering this question a description of a categorizing of the research into sub-topics formerly done by Dalen \& Ogden (2008) and by Bachke (2011) will be presented. In addition, a Norwegian educator's division of perspectives within SNE will be described. This knowledge serves as a background for analyzing and discussing the findings.

\section{The status of the Norwegian IEP research}

The Norwegian research has so far been scarce. Most publications are found in chapters in anthologies of SNE, that is text books for students of the discipline (Rygvold \& Ogden 2008); subject-articles in the journal Spesialpedagogikk; master-theses; legally linked texts; and in encyclopedias at the Internet. Any recent and thorough summary of this research does not exist. In 2008 Dalen \& Ogden (professors of SNE) presented a brief "survey" of important sub-topics described by Norwegian researchers until that year. They included these themes:

(1) The importance and value of the stage of planning was strongly emphasized by the teachers who were involved.

(2) The guidelines for planning an IEP state clearly that the pupil himself as well as his/her parents should be involved in the process. Research showed that the parents wished to be involved. However, in most cases the teachers worked out the plan alone before showing it to the pupil and his/her parents (for signing).

(3) The IEP should be a written document, available for all it might concern. Research showed that teaching based on such a shared document was of a higher quality than education implemented without a written IEP.

(4) The onset of an IEP is a thorough examination of the pupil's abilities and disabilities done by the school psychologist and other educational specialists. Their expert statements were to a certain extent reported to be too abstract and general. Subsequently, the teachers in charge of writing the IEP found them less pragmatic and helpful.

(5) The teachers assessed that they lack necessary competence to work out IEPs. Therefore they asked for both post-qualifying education and supervision.

(6) Research identified some dilemmas connected to the use of the IEP, like the IEP drastically reduced the teacher's traditional space of freedom to do the work in his/her own way; the IEP counteracted the idea of inclusion; in some cases there might be doubt as to who was responsible for working out the IEP: the special educator or the form master. 
Bachke (2011) did a smaller review of American IEP-topical peer reviewed articles, sampled from ERIC (EBSCO), published until 2010.It showed that the American contribution of research is larger in numbers, and that the following themes were the most frequently focused:

(1) IEP and goals: The importance of stating, writing and concretizing goals

(2) IEP: Training in writing the plans

(3) IEP: How to make plans that are functional

(4) IEP: What prevents it from being used properly, and how to reduce obstacles?

(5) Information Technology (IT), might it be helpful in practical use of IEP?

(6) IEP-meetings: How to make conversations effective and functional?

(7) IEP and how to improve the empowerment of and co-operation with pupils and their parents, in particular increasing their participation

(8) IEP and ethnicity

(9) IEP and legal issues

Table 1 summarizes the research presented above. It consists of three columns. Column 1 deals with which stage of the IEP-research findings are mostly related to, either the preparation and writing of the plan (row I); or the use of the plan (row II). In addition, there is a row III; other issues. Column 2 relates the six sub-topics mentioned by Dalen \& Ogden and links them to the three rows of column 1. Column 3 does the same with the nine American subcategories. References to some Norwegian master theses published in 2009-10 are included in column two to update it until 2010.

Table 1. A summary of main themes and sub-topics of IEP-research by 2010

\begin{tabular}{|l|l|l|}
\hline $\begin{array}{l}\text { Main categories of } \\
\text { IEP-research }\end{array}$ & $\begin{array}{l}\text { Examples of Norwegian sub- } \\
\text { topics of research until 2010 }\end{array}$ & $\begin{array}{l}\text { Examples of American sub- } \\
\text { topics of research until 2010 }\end{array}$ \\
\hline $\begin{array}{l}\text { (I) Knowledge } \\
\text { related to the } \\
\text { preparation and } \\
\text { planning stage }\end{array}$ & $\begin{array}{l}\text { The insufficient involvement } \\
\text { of pupils and their parents in } \\
\text { the planning process }\end{array}$ & $\begin{array}{l}\text { How to improve the } \\
\text { empowerment and co-operations } \\
\text { with pupils and their parents }\end{array}$ \\
\cline { 2 - 3 } & $\begin{array}{l}\text { Weaknesses linked to the } \\
\text { language and concreteness of } \\
\text { the expert statements; } \\
\text { Thorbjørnsen (2009) }\end{array}$ & \\
\hline & $\begin{array}{l}\text { Teachers' lack of competence } \\
\text { in writing and making the } \\
\text { written IEP-document; Aarvik } \\
(2009)\end{array}$ & $\begin{array}{l}\text { Teachers' need of training in } \\
\text { working out the IEPs } \\
\text { How to make functional IEPs }\end{array}$ \\
\cline { 2 - 3 } & $\begin{array}{l}\text { Teachers' emphasis on the } \\
\text { importance of a proper } \\
\text { planning stage }\end{array}$ & $\begin{array}{l}\text { The importance of stating and } \\
\text { writing concrete IEP-goals }\end{array}$ \\
\hline
\end{tabular}




\begin{tabular}{|l|l|l|}
\hline $\begin{array}{l}\text { (II) Knowledge } \\
\text { related to the } \\
\text { (use)implementing } \\
\text { stage }\end{array}$ & $\begin{array}{l}\text { The written IEP has a positive } \\
\text { impact on the quality of } \\
\text { teaching; Holst-Jæger (2009) }\end{array}$ & $\begin{array}{l}\text { IT - a helpful tool in practical } \\
\text { use of IEPs }\end{array}$ \\
\cline { 2 - 3 } & $\begin{array}{l}\text { Identified dilemmas in using } \\
\text { IEPs }\end{array}$ & $\begin{array}{l}\text { What might be preventive } \\
\text { obstacles, and how to reduce } \\
\text { them }\end{array}$ \\
\hline (III) Other issues & $\begin{array}{l}\text { IEP collaborative meetings, how } \\
\text { to make conversation effective } \\
\text { and functional }\end{array}$ \\
\cline { 3 - 3 } & $\begin{array}{l}\text { IEP and legal issues } \\
\end{array}$ & \begin{tabular}{l} 
IEP and ethnicity \\
\hline
\end{tabular} \\
\hline
\end{tabular}

\section{Various perspectives of SNE}

Haustätter (2007) introduced various perspectives applied in SNE, representing different ways of thinking and acting in the field. The pathological perspective, also named the traditional or narrow perspective (Hausstätter, 2011 ; 2012), focuses on the biological and psychological deficiencies of the pupil as the main cause for slow learning and inability to benefit from the ordinary educational program.Subsequently the pupil needs special educational approaches that may "cure" or "reduce" his/her insufficient learning progress. The assistance offered is mostly based on methods and tools which have evidentially proved helpful for pupils affected by similar diagnoses. Like patients treated in a hospital, these pupils are offered a segregated educational program both because it will be tailor-made for them and at the same time not disturbing the pupils who are learning at a "normal speed".

The organizational perspective looks at dysfunctional learning differently: The pupil's problems are seen as reactions to the organizational systems and structures offered by society. It is argued that most pupils will have arenas where he/she does not appear to misbehave/learn slowly. Subsequently, to assist these pupils one should look for structural solutions that promote solid learning and avoid unsatisfactory systems, like physical hindrances. In brief, the environment should be organized in both an accessible and learning-promoting way for everyone, to avoid any form of stigmatization.

The social perspective is partly connected to the latter perspective, but it emphasizes more strongly that dysfunctions are considered a product of how we understand the society: Basically no one is dysfunctional. It is the society that creates barriers for the individual and thereby prevents him/her from proper learning and growth which then leads to marginalization. The aim of this perspective is to avoid exclusion and promote what Hausstätter (2011) calls inclusionism. This is the opposite of particularly the first perspective, also nicknamed traditionalism. In the analyses of the literature this dichotomy of inclusionism and traditionalism will be used. 


\section{Method}

Aveyard (2010:1) defined literature review as "the comprehensive study and interpretation of literature that relates to a particular topic." It may be more or less systematic. If it is the latter - the so called narrative review, the methods of searching and synthesizing the literature are not or poorly described. If the review is systematic, the methods of searching, critiquing and synthesizing the literature are explicitly stated and rigorously followed. The present study belongs to the latter category.

The literature search has been based on the Norwegian data base ORIA. The Norwegian concept Individuell opplæringsplan (abbreviated IOP) was used and publication period was limited to 2010-2015. The search was done on $17^{\text {th }}$ of Feb. 2015, and resulted in 23 hits. Except for one book-chapter the hits were either master theses or peer reviewed articles. This number is higher than for any previous five-year-period since 1990. Some hits were doubled and some of less relevance. So the total number of analyzed items was 11 . The analyses of these items are presented under "Findings" below. The analytic categories used are type of publication; method(s) of research applied; categories of table 1; and Hausstätter's perspectives of SNE traditionalism and inclusionism.

\section{Findings}

The sample consists of two types of scientific literature: The three peer reviewed articles, presented firstly; and the eight master theses, presented secondly.

Thygesen et al (2011) did a literature review of white papers and former research articles presenting the effects of SNE, looking at the legitimacy and role of SNE in relation to the general education in schools. Inter alia the researchers argued that special pedagogy is a necessary competence to attain the ideal aim of an inclusive school. In addition they underscore the dilemma of "creating" an adaptive education tailor made plan for each pupil, like the IEP, without at the same time reducing the level of belonging to an inclusive community. Thematically, Thygesen et al dealt mainly with dilemmas of using the IEP; and they linked this to the perspective of inclusionism.

Haug (2011) also dealt with the question of dividing general education and SNE, and how this might affect the education of all the pupils. By means of observing the activities in 45 classrooms Haug found that pupils that received SNE showed a lower level of learning related activity than "ordinary" and clever pupils. Haug interpreted this as if the former pupils had an education of poorer quality. He contended that this might be a side effect of the gap existing between the two professional curricula, special pedagogy and general pedagogy respectively. Also Haug's findings related to the sub-topic dilemmas in using IEP; and his study threw light on controversies linked to inclusionism. 
Runde (2013) focused on the sub-topic of IEP and legal matters by means of reviewing laws and legal cases. He looked at the liability of damages and its terms of compensation in cases where the basic resources of SNE had been insufficiently offered by the school owner, i.e. most often the local municipality. Among the flaws, the author referred to the Educational Act statement of §5-5: "If special needs education is granted, an IEP should be made."If the IEP lacked, appeared too limited or not properly used, it represented a breach of the legal individual rights of the pupil. Runde's focus on the individual is interpreted as a connection to the perspective of traditionalism.

Nergaard \& Hauge (2011) applied a hermeneutic approach to analyze documents like the written IEPs and expert statements and detect how these written papers corresponded, item by item. The findings showed that both the statements and the IOPs referred to the laws and regulations, but in some cases insufficiently. Moreover the aims stated were assessed to be both general and not very realistic. To a certain extent the IOPs were marked by standardized statements which might be a sign of "copy paste" practice among the professionals in charge of writing them. It was concluded that the school faced difficulties in making aims for each pupil, based on the expert statements. Thematically this research linked partly to the sub-topic weaknesses of expert statements, and partly the teachers' lack of skills to formulate aims. One purpose of the study was to look for ways to improve the statements and the aims of IEPs, which attends to the perspective of traditionalism.

Kvilhaugsvik (2011) looked at the statement of aims in IEPS for pupils with dyslexia, and assessed to which extent they were precise, relevant, communicable and evaluable. Among the seven categories of aims she classified, she found only two of sufficiently good standard. Furthermore, she compared the content of the aims with the content required for improving skills of reading. She partly found a match (for decoding text), but also partly a mismatch (for understanding the text). The latter worried the researcher: Is it probable that the aims prevent pupils' progress in reading? Thematically this study belongs to the sub-topic: The importance of stating and writing concrete IEP-goals; and subsequently the perspective of traditionalism.

Halvorsen (2011) analyzed the IOP-documents of pupils in secondary schools who received an education with extended practice due to learning difficulties in theoretical subjects. In addition she interviewed both pupils of two small classes and their teachers, and did field observations during one schoolweek. The findings showed that the quality of IEPs varied between the classes both in volume, how general the language was, and how concrete the goals and content were stated. The observations underscored that the class with more complete and specific IOP formulated plans experienced a teaching which was more dedicated and relational and of better quality. The same impression was confirmed in the interviews of pupils and teachers, although the two classes were exposed to two different "educational cultures". Thematically the study 
supports the positive impact of a detailed written IEP has on the teaching. It focused on the use of the IEP and thereby belongs to the perspective of traditionalism.

Heldal (2012) used analyses of IEP-documents and a questionnaire to caregivers of ADHD-diagnosed pupils to throw light on how the aim of inclusion was expressed in the documents and the level of involvement of the caregivers in the development of the IEP. She operationalized inclusion by means of three areas: to increase fellowship belonging and participation (these two factors were measured by document-reading/-interpretation), and to increase democratization (also enlighten by answers in the questionnaire). She found that the IEPs expressed inclusive elements, cf. the three areas. However, the information statements were difficult to match directly with operationalization which made assessing difficult. The study also showed that the IEPs could be improved to express more clearly how inclusion could be obtained. The caregivers expressed that they were included in the development of their children's IEPs. This finding underpins a variant of the sub-topic "involvement of parents in the planning process", in a positive way. The study's focus on inclusion shows that it mainly belongs to the perspective of inclusionism.

Kvam (2013) combined two methods in order to illuminate how teachers work to accomplish the intents of the IEP. She interviewed a small sample of teachers, and also collected data from a questionnaire of a bigger sample of teachers. Kvam found that IEP proved to be a profitable tool to assure the quality of a customized education in accordance with the pupil's legal rights. Moreover, the study showed how important the teachers' knowledge of each pupil was and also that SNE was organized in different ways. The informants generally reported that the pupils according to their assessment felt included in the school society. The need of more resources to meet the requirements of the laws and regulations was also stated. Thematically the study partly belongs to the sub-topic IEP's positive impact on the quality of teaching; and partly, through the statement about the need of more resources, to the sub-topic how to reduce obstacles. These two sub-topics relate both to the perspective of traditionalism. However, the statement of "felt inclusion" refers to a positive variant of inclusionism, because a proper use of IEP makes it more obtainable.

Olsen (2013) used a survey to enlighten the participation of mothers of kindergarten children in developing IEPs. She found that there was a correlation between the mothers' feeling of influence/participation and their amount of Bourdieu's social capital concept. However, due to a too low number of respondents this could not be generalized. Thematically this is a positive variant of the sub-topic parents' involvement in the planning process. This study was a smaller project under a major project investigating to which extent kindergarten as a public institution promoted integration. In that way it might attend to the perspective of inclusionism. On the other hand, the main finding is related to 
positive experiences of participating in IEP-planning, which might be assessed as traditionalistic. So this study bears elements of both perspectives.

Solem (2014) studied what teachers experienced as helpful support when working out an IEP. By means of interviewing a sample of teachers she found that (a) collaboration with the pupils' homes, colleagues, and external experts; and (b) the involvement and arrangement of the management of the school both constituted essential support. However, (c) the "pragmatics" of the expert statements could vary. Thematically this study partly by finding (c) attends to the sub-topic weaknesses of expert statements; and partly by findings (a) and (b) to a variant of the sub-topic importance of a proper planning stage. With its focus on helpful experiences it belongs to the perspective of traditionalism.

Walden (2014) explored by means of in-depth interviews of parents, teachers and principals facilitating and inhibiting factors in the collaboration between home and school in developing IEPs. She found as a facilitating factor the professionals' and parents' dedication for the pupils' thriving and development, which emphasizes the sub-factor of involvement mentioned above. The inhibiting factors were several like lacks of time, unclear structure, blurry roles and unsatisfactory communication between home and school. Thematically this study adheres to the sub-topic of co-operation with parents, partly a positive variant (the facilitating factor), and partly a negative variant (the inhibiting factors). Since it points to possible improvements in the IEPcollaboration, it belongs to the perspective of traditionalism.

Table 2 presents an analytical summary of the findings.

Table 2. Summary of findings, analyzed by means of the theoretical categories

\begin{tabular}{|l|l|l|l|l|}
\hline $\begin{array}{l}\text { Analytic } \\
\text { variable } \\
\text { Item }\end{array}$ & $\begin{array}{l}\text { Column I: } \\
\text { Type of } \\
\text { publication }\end{array}$ & $\begin{array}{l}\text { Column II: } \\
\text { Research } \\
\text { method(s) applied }\end{array}$ & $\begin{array}{l}\text { Column III: } \\
\text { Sub-topics focused }\end{array}$ & $\begin{array}{l}\text { Column IV: } \\
\text { Perspective of } \\
\text { SNE related } \\
\text { to }\end{array}$ \\
\hline $\begin{array}{l}\text { Thygesen et } \\
\text { al (2011) }\end{array}$ & $\begin{array}{l}\text { Peer reviewed } \\
\text { article }\end{array}$ & $\begin{array}{l}\text { Document } \\
\text { analysis: white } \\
\text { papers, laws }\end{array}$ & $\begin{array}{l}\text { IEP-dilemmas } \\
\text { neg. }\end{array}$ \\
\hline Haug (2011) & $\begin{array}{l}\text { Peer } \\
\text { reviewedarticle }\end{array}$ & $\begin{array}{l}\text { Classroom } \\
\text { observations }\end{array}$ & IEP-dilemmas & $\begin{array}{l}\text { Inclusionism, } \\
\text { neg. }\end{array}$ \\
\hline $\begin{array}{l}\text { Runde } \\
(2013)\end{array}$ & $\begin{array}{l}\text { Peer } \\
\text { reviewedarticle }\end{array}$ & $\begin{array}{l}\text { Document } \\
\text { analysis: white } \\
\text { papers, laws, court } \\
\text { cases }\end{array}$ & IEP and legal issues & $\begin{array}{l}\text { Traditionalism, } \\
\text { neg. }\end{array}$ \\
\hline $\begin{array}{l}\text { Nergaard \& } \\
\text { Hauge } \\
(2011)\end{array}$ & Master thesis & $\begin{array}{l}\text { Document } \\
\text { analysis: IEPs and } \\
\text { expert statements }\end{array}$ & $\begin{array}{l}\text { Weaknesses of } \\
\text { expert statements; } \\
\text { lack of skills to } \\
\text { word aims }\end{array}$ & $\begin{array}{l}\text { Traditionalism, } \\
\text { neg. }\end{array}$ \\
\hline $\begin{array}{l}\text { Kvilhaugsvik } \\
(2011)\end{array}$ & Master thesis & $\begin{array}{l}\text { Document } \\
\text { analysis: IEPs }\end{array}$ & $\begin{array}{l}\text { Not good enough } \\
\text { wording of aims }\end{array}$ & $\begin{array}{l}\text { Traditionalism, } \\
\text { neg. }\end{array}$ \\
\hline
\end{tabular}


SOCIETY. INTEGRATION. EDUCATION. Volume III

\begin{tabular}{|c|c|c|c|c|}
\hline $\begin{array}{l}\text { Halvorsen } \\
(2011)\end{array}$ & Master thesis & $\begin{array}{l}\text { Document } \\
\text { analysis: IEPs, } \\
\text { field observation, } \\
\text { interviews of } \\
\text { pupils and teachers }\end{array}$ & $\begin{array}{l}\text { Positive impact of } \\
\text { detailed written } \\
\text { IEPs }\end{array}$ & $\begin{array}{l}\text { Traditionalism, } \\
\text { pos. }\end{array}$ \\
\hline $\begin{array}{l}\text { Heldal } \\
(2012)\end{array}$ & Master thesis & $\begin{array}{l}\text { Document analysis } \\
\text { of IEPs, } \\
\text { questionnaire }\end{array}$ & $\begin{array}{l}\text { The inclusion of } \\
\text { caregivers in } \\
\text { developing the IEP }\end{array}$ & $\begin{array}{l}\text { Traditionalism, } \\
\text { pos. }\end{array}$ \\
\hline Kvam(2013) & Master thesis & $\begin{array}{l}\text { Interviews of } \\
\text { teachers, }+ \\
\text { collection of data } \\
\text { from a survey }\end{array}$ & $\begin{array}{l}\text { IEP's positive } \\
\text { impact on the } \\
\text { quality of teaching, } \\
\text { need of more } \\
\text { resources to reduce } \\
\text { obstacles }\end{array}$ & $\begin{array}{l}\text { Traditionalism, } \\
\text { both neg. and } \\
\text { pos. }\end{array}$ \\
\hline Olsen (2013) & Master thesis & $\begin{array}{l}\text { Survey among } \\
\text { mothers of } \\
\text { kindergarten } \\
\text { children with IEP }\end{array}$ & $\begin{array}{l}\text { Positive } \\
\text { involvement of } \\
\text { parents in the } \\
\text { planning process } \\
\text { Kindergartens as an } \\
\text { institution } \\
\text { promoting } \\
\text { integration }\end{array}$ & $\begin{array}{l}\text { Traditionalism, } \\
\text { pos. } \\
\text { Inclusionism, } \\
\text { pos.? }\end{array}$ \\
\hline $\begin{array}{l}\text { Solem } \\
(2014)\end{array}$ & Master thesis & $\begin{array}{l}\text { Interviews of } \\
\text { teachers about } \\
\text { collaboration with } \\
\text { parents, experts, } \\
\text { colleagues }\end{array}$ & $\begin{array}{l}\text { Weaknesses of } \\
\text { expert statements, } \\
\text { proper planning } \\
\text { stage important }\end{array}$ & $\begin{array}{l}\text { Traditionalism, } \\
\text { both neg. and } \\
\text { pos. }\end{array}$ \\
\hline $\begin{array}{l}\text { Walden } \\
\text { (2014) }\end{array}$ & Master thesis & $\begin{array}{l}\text { Interviews of } \\
\text { parents, teachers, } \\
\text { principals }\end{array}$ & $\begin{array}{l}\text { IEP-collaboration } \\
\text { and development } \\
\text { promoted by the } \\
\text { informants' } \\
\text { dedication for the } \\
\text { child; + positive } \\
\text { involvement of } \\
\text { parents }\end{array}$ & $\begin{array}{l}\text { Traditionalism, } \\
\text { pos. }\end{array}$ \\
\hline
\end{tabular}

\section{Findings commented and discussed}

In the following the findings of each of the four analytic columns of table 2 will be commented and discussed, one by one. Column I, Type of reviewed publications, is divided into two categories: Referee articles $(\mathrm{N}=3)$; and master theses $(\mathrm{N}=8)$. The total of 11 relevant Norwegian publications, registered during 2010-2015, is higher than any previous five year period since the introduction of the IEP around 1990. This implies primarily that research in this field, although still scant, is slowly increasing. Secondly, the figure 3 indicates that few full-fledged researchers, holding a $\mathrm{PhD}$, are directly involved in this field's research. One should also notice that one of the articles is written by Runde (2013), who is a trained in the legal profession. It emphasizes that the 
phenomenon of IEP challenges other professionals than the educators: something which is also indicated by former American research stating that IEP and legal issues is an important topic, cf. table 1. The fact that 8 out of 11 publications are master theses may be seen as a sign of high interest for IEPs in the every-day practical life of schools and kindergartens. Master's students in SNE in Norway often either have years of practice behind them when they reach this level of study, or they do it as a part-time-study, combined with work. Seen in this light, the figure of 8 theses indicates that the research done is solidly founded in issues based in practical experiential IEP-settings. Subsequently these theses, if read, ought to have valid impact on both planning and use of IEPs.

Column II, Research method applied, primarily shows that these 11 studies comprise four methods: Observations (2); surveys/questionnaire s (3); interviews (4) and document analyses (6). Secondly, one should notice that no meta-theoretical review article has been published in Norway during this period. This fact indicates that thorough summaries of previous national and international research related to the IEP are deeply needed. Thirdly, the document analyses concentrate mainly on two types of documents: The expert statements; and IEP-documents. These are beyond doubt the most crucial documents, but there are other IEP school documents to be investigated too, like budgets, plans of disposition of personnel, minutes from meetings deciding the use of resources, minutes from meetings of commitment groups in charge of IEP-planning and -implementation, the SNE-teachers' and form masters' preparatory books/planning and evaluative comments, etc. Fourthly, the samples of the interview-informants show that only one study so far has included the pupils themselves. Fifthly, the scarcity of observational studies is conspicuous to the extent that it is almost equal to a white spot on the map of IEP-research.

Column III, Sub-topics focused, reveals first of all that at large the research published in 2010-15, focuses on the same topics as in table 1 . However, there are two major differences: In table 1, most findings are related to problems in planning, writing and using the IEPs, while in table 2 half of the findings are positively pointing to IEP's usefulness and impact on the quality of SNE. The last 5 years research has so to speak looked more for success factors than previous years' research. Secondly, table 1 dichotomized between a planning stage and a implementing stage as main categories, plus a general "other"category. Table 2 indicates several findings by means of "investigating the IEP documents" themselves. This fact makes it reasonable to suggest a fourth main area of research: the IEP document itself, detached from the stages and processes connected to planning and using. Such a category might, however, be a less valid research object. Because it is separated from the professionals using it, it appears more "dead" and non-dynamic, and subsequently a narrower source of knowledge. 
Bachke (2011) pointed to a lack of a separate didactical tool for SNE, which could step by step describe an application of the main didactical factors of aims, content, methods/teaching principles/learning activities and evaluation. One would think that the research of IEPs in use would detect more knowledge about how such factors are applied in SNE. However column III explicitly refers to the aim factor only, and then emphasizes the importance of formulating the goals concretely (cf. Kvilhaugsvik, 2011). I therefore contend that since IEP is a didactical tool, the future research should pay more attention to how teachers and other professionals involved make use of didactical knowledge in connection with IEP work. The IEPs offer a unique opportunity to develop the didactics of SNE.

In Column IV, Perspectives of SNE, the figures show a distribution of 8.5 studies belonging to the traditional perspective while 2.5 studies mainly adheres to inclusionism. I interpret the significantly higher figure relating to the former as if most researchers basically believe the IEP is a useful tool which faces some problems (cf. the 4 neg. in the column) that still prevent a full practical functionality. Therefore it is an important research task to identify those obstacles, and possibly point to how they might be overcome. On the other hand, the traditionalism pos. of Halvorsen, Heldal, Solem, Kvam, Olsen and Walden might hint at some success factors, or at least underlining the value of a positive research approach, looking for factors promoting successful practice. The inclusionism-studies might represent a critical methodological approach since it mainly, in particular among the scholars, voices negative side effects of using IEP like making segregation and possibly stigmatization more explicit. However, the voice of the mothers in Olsen's study (2013) might imply that some researchers as well as some actors in this field experience the IEP as promoting inclusion. In other words, they might suggest that there are ways of using IEP which facilitate inclusion. If so, this fact ought to inspire researchers to detect these ways explicitly, and to describe more in detail in which contexts they operate positively and functionally.

\section{Conclusions}

The research question was: What characterizes the research of SNE's use of IEP, during the period 2010-15? Primarily, this study supports the impression that the Norwegian contribution to IEP-research is still scarce. Secondly, it shows that only a few researchers holding a PhD have participated in this research sample. Thirdly, it reveals a wide use of research methods applied in the reviewed sample of publications. Some researchers have even applied 2-3 methods. However, the fact that half of the sampled reviewed studies have applied document analysis as their main approach underpins the lack of empirical research. It should also be remarked that no research project during this period has been of the longitudinal kind. Moreover, only one study partly 
voices the experiences of the pupils. A fourth characteristic is that a systematic research of good ways of formulating the IEP-document to detect catalysts of the planning stage is still missing to a great extent. The same goes for the implementing stage. Until now the focus has been more on the problems, weaknesses and dilemmas. However, this review reveals that there are some signs of studies identifying what might be called "best practice of IEP work". Fifthly, this review has introduced one way of constructing topical categories, both on a general level and implying some sub-categories. This classification will need a broader international review to prove its validity and reliability. For now, it might serve as a starting point for further studies. Lastly, generally few researchers place themselves in a specific perspective of SNE. My attempts to put them into the dichotomy boxes may therefore contain mistakes. However, the unstated perspective of SNE leads me to claim that there is a need for more research on how basic scientific views might affect the findings of any IEP research project.

\section{References}

Aarnes, A. (2008). IOP i praksis. Individuelle planer og tilpasset opplaering. Oslo: Pedlex Norsk Skoleinformasjon.

Aarvik, A. K. (2009). Hvordan kan skolen legge til rette for a a tilby elever med spesielle opplaringsbehov en yrkesutdanning gjennom en individuell opplaringsplan. Lillestrøm: Høgskolen i Akershus.

Aveyard, H. (2010). Doing a Literature Review in Health \& Social Care, a Practical Guide. Maidenhead, Birkshire: Open University Press/McGraw-Hill.

Bachke; C. C. (2011). Individuelle opplæringsplaner - mye brukt, men lite utforsket. Spesialpedagogikk. 76, 10, 4-18.

Dalen, M. \& Ogden, T. (2008). Spesialpedagogikk og spesialpedagogiske tiltak. In Rygvold, A-L. \& Ogden, T. (Eds.): Innføring $i$ spesialpedagogikk, (pp.383-409). Oslo: Gyldendal akademiske.

Halvorsen, M. (2011). IOP i utvidet praksis: elev og lacrererfaringer. Master thesis; Stavanger: University of Stavanger, Department of Education and Special Education.

Haug, P (2011). God opplæring for alle - eit felles ansvar. Norsk Pedagogisk Tidsskrift, 95, 2, $129-140$.

Hausstätter, R. S. (2007). Spesialpedagogiske grunnlagsproblemer: mellom ideologi og virkelighet. Bergen: Fagbokforlaget.

Hausstätter, R. S. (2011). The Traditionalism-Inclusionism Controversy in Special Education: a Conceptual Analysis; Doctoral Dissertation (article-based); University of Helsinki: Faculty of Behavioral Science.

Hausstätter, R. S. (2012). Den individuelle opplæringsplanen som strategisk document. In Hausstätter, R. S. (2012, ed.): Inkluderende spesialundervisning. Bergen: Fagbokforlaget.

Heldal, E. (2012). Individuelle opplaringsplaner og inkludering: en dokumentanalyse av individuelle opplceringsplaner. Master thesis. Bergen: NLA Høgskolen (University College); Department of Education.

Holst-Jæger, J. (2009). Arbeid med individuelle opplæringsplaner. Spesialpedagogikk, 74, 9, 28-35. 


\section{SOCIETY. INTEGRATION. EDUCATION. Volume III}

Kunnskapsløftet (2006). Innføring av Kunnskapsløftet:Om fag- og timefordeling $i$ grunnopplceringen, tilbudsstrukturen m.m. Oslo: Kunnskapsdepartementet; Serie Rundskriv F 12/2006 B.

Kvam, A. (2013). Porten til virkeligheten: En fenomenologisk studie av loereres arbeid med å realisere intensjonen med individuelle opplaeringsplaner. Trondheim: NTNU Open, Department of Education.

Kvilhaugsvik, S. (2011). I hvilken grad gir individuelle opplaeringsplaner $i$ norsk til elever med store lesevansker grunnlag for vurdering av framgang $i$ leseferdighet? Master thesis, Stavanger: Universitetet i Stavanger, Faculty of Arts and Education.

Nergaard, B. I. \& Hauge, A. J. (2011). Sakkyndig vurdering og individuell opplaringsplan; innhold og sammenheng: en dokumentanalyse. Master thesis. Oslo: Universitetet i Oslo, Institutt for spesialpedagogikk.

Nordahl, T \& Overland, T. (1997). Individuelle opplceringsplaner. Oslo: Ad Notam Gyldendal.

Olsen, T. (2013). Selvopplevd foreldremedvirkning i barnehagen og i utforming av individuell opplceringsplan: En kvantitativ studie av kvaliteten av samarbeidet mellom foreldre til barn med nedsatt funksjonsevne og barnehagepersonalet $i$ barnehagen hvor barnet deres tilhører. Master thesis. Trondheim: NTNU Open, Department of Social Work and Health Science.

Runde, A. (2013). Skoleeiers erstatningsansvar for mangelfull opplæring i offentlige skoler. Lov og rett, 52, 6, 428-447.

Rygvold, A-L. \& Ogden, T. (Eds., (2008). Innføring i spesialpedagogikk. Oslo: Gyldendal akademiske.

Solem, I (2014). Hjelp og støtte ved utforming av IOP til elevar med alvorleg grad av cerebral parese: Ei kvalitativ studie av loerarar si oppleving av hjelp og støtte ved utforming av individuelle opplaringsplaner og korleis denne hjelpa kunne blitt gjort betre. Master thesis, Trondheim: NTNU Open, Institutt for pedagogikk.

St.meld. no.54 (1989-90). Om opplaering av barn, unge og voksne med scerskilte behov. Oslo: Kirke-, utdannings- og forskingsdepartementet (White paper).

St.meld. no.35 (1990-91): Tillegg til St.meld. $n r .54$ (1989-90). Oslo: Kirke-, utdannings- og forskingsdepartementet (White paper).

St.meld. nr. 20 (2012-2013): På rett vei. Oslo: Utdanningsdirektoratet (White paper).

Thorbjørnsen, L. K. S (2009). Fra sakkyndig vurdering til individuell opplaeringsplan: En dokumentanalyse av hvordan sakkyndig vurdering blir vektlagt $i$ utarbeidelsen av individuell opplaeringsplan. Master thesis. Oslo: Universitetet i Oslo, Institutt for spesialpedagogikk.

Thygesen, R., Briseid, L. G., Tveit, A. D., Cameron, D. L. \& Bobo, V. K. (2011). Er generell pedagogisk kompetanse tilstrekkelig for å sikre en inkluderende skole? Norsk Pedagogisk Tidsskrift, 95, 2, 103-114.

Walden, J. (2014). A qualitative study of collaboration between principals, teachers and the parents of children with special needs. Master thesis. University of Bergen; Faculty of Psychology. 